\title{
THE STABILITY OF CHLOROGENIC ACID IN SYRUP OF COFFEE ARABICA (COFFEA ARABICA L.) EXTRACT WITH DECAFFEINATION PROCESS
}

\author{
ARIF BUDIMAN*, ANGGI LUTFHI, MUCHTARIDI M
}

Department of Pharmaceutical and Technology Pharmacy, Universitas Padjadjaran, Indonesia. Email: arifbudimanapt@gmail.com

Received: 06 November 2016, Revised and Accepted: 30 January 2017

ABSTRACT

Objective: This research aims to formulate syrup of coffee arabica extract with decaffeination process and stability test of caffein and chlorogenic acid (CGA) in syrup of coffee arabica extract.

Materials and Methods: An extraction was conducted by using ethanol $70 \%$ with soxhletation methods, and decaffeination process (using liquid-liquid extraction with ratio of ethanol and dichloromethane was 1:1). Syrup formulations of coffee arabica extract were made with various concentrations of Na carboxymethylcellulose (CMC) (thickening agent) and sucralose (flavoring agent). The stability of syrup was evaluated through organoleptic, pH, viscosity, hedonic test, microbiological test and determinated concentration of caffeine and CGA.

Results: The result showed that the concentration of caffeine before and after decaffeination process was $3.377 \pm 0091 \%$ and $1.028 \pm 0.079 \%$. While CGA was $4.159 \pm 0.163 \%$ and $3.019 \pm 0.138 \%$. Microbiological test showed that no contamination in syrup of coffee arabica extract. The concentration of caffeine in syrup of coffee arabica extract was $1.070 \pm 0.150 \%$ and CGA was $4.432 \pm 1.98 \%$.

Conclusion: The concentration of caffeine before and after formulation process was $3.019 \pm 0.138 \%$ and $4.432 \pm 1.986 \%$. The best formula of coffee arabica extract syrup was the formula that contains $5 \mathrm{mg} / \mathrm{ml}$ of coffee arabica extract, $1.5 \mathrm{mg} / \mathrm{ml} \mathrm{of} \mathrm{Na} \mathrm{CMC}$, and $0.5 \mathrm{mg} / \mathrm{ml}$ of sucralose and no contamination in syrup of coffee arabica extract. Caffeine content would decrease after the decaffeination process.

Keywords: Chlorogenic acid, Coffee arabica extract, Syrup, Decaffeination, Caffeine.

(C) 2017 The Authors. Published by Innovare Academic Sciences Pvt Ltd. This is an open access article under the CC BY license (http://creativecommons. org/licenses/by/4. 0/) DOI: http://dx.doi.org/10.22159/ajpcr.2017.v10s2.19469

\section{INTRODUCTION}

Indonesia is one of the largest countries producing Arabica coffee in the world. Coffee has been consumed for over 1000 years and making this as the most consumed drink in the world. Coffee contains many active substances such as fenol, flavonoid, mineral, and sugar. Yet, the most widely known compounds in coffee are chlorogenic acid (CGA) and caffeine $[1,2]$.

CGAs are the main phenolic compounds in coffee and can be found in coffee within high concentration [3], for instance: Green coffee contains (5-12 g/100 g) of CGA. CGA is believed to have antioxidant properties which can protect food, cells and any organ from oxidative degenerative. CGA compound is important in preventing various diseases associated with oxidative stress such as cancer, cardiovascular, aging, and neurodegenerative disease. CGA also can be considered as an antiviral, which can inhibit the influenza virus, herpes virus herpes simplex virus Type 1 (HSV-1), HSV-2, and adenovirus [4-6]. In particular, CGA has a function as a brain protector in the treatment of neurodegenerative diseases, such as Alzheimer, Parkinson, and ischemia [7].

Coffee beans contain caffeine that has a pharmacological effect, such as stimulating the central nervous system and relaxing the smooth muscle, especially bronchial and cardiac muscles [8]. Caffeine consumption in the long term can affect the suppression of energy metabolism by causing adrenal fatigue [9]. Previously, descriptive studies indicated that consuming caffeine can cause insomnia, headache, tremor, anxiety, nausea and vomiting [10]. Therefore, it is necessary to reduce the level of caffeine in coffee beans.

Decaffeinated coffee is good for health, especially in gastric disorders. The use of decaffeinated coffee increased and reached $10 \%$ of the overall coffee consumption [11]. Decaffeination process usually uses organic solvents such as dichloromethane and ethyl acetate [4]. According to the previous study, dichloromethane $(140 \mathrm{mg} / \mathrm{ml})$ has better ability on dissolving the caffeine compared to water $(22 \mathrm{mg} / \mathrm{ml})$ [12].

\section{MATERIALS AND METHODS}

\section{Materials}

Arabica coffee (Pasir Mulya Village, Pengalengan, Kabupaten Bandung), ethanol 70\% (PT Brataco), aquadest, aquabidestilata, toluene (PT Brataco), Mayer reagent (Merck), Dragendorff reagent (Merck), Lieberman-Burchard reagent (Merck), chloroform (PT Brataco), ammonia (PT Brataco), chloride acid 2N (PT Brataco), gelatin 1\% (Merck), $\mathrm{FeCl}_{3}$ (Merck), magnesium powder (Merck), amyl alcohol (Merck), ether (PT Brataco), methanol (PT Brataco), dichloromethane (PT Brataco), acetic acid (PT Brataco), potassium hydroxide solution 5\%, n-hexane (PT Brataco), sucralose (Kimia Mart), citric acid (CV. Chemco Prima Mandiri), and sodium benzoate (PT Brataco).

\section{Methods}

Extraction

Coffea arabica L. powder was extracted with ethanol $70 \%$ using soxhletation methods. Each extract was evaporated by using a rotary evaporator at $50-60^{\circ} \mathrm{C}$ and followed by water bath at $40^{\circ} \mathrm{C}$ [13]. Extract was determined including specific standardized and non-specific standardized extracts [14].

\section{Phytochemical screening}

Phytochemical screening for secondary metabolites was performed by following standard procedures, including alkaloids, polyphenol, tannin, flavonoid, monoterpen, seskuiterpen, steroid, triterpenoid, kuinon, and saponin test [15]. 


\section{Decaffeination process}

The extract was partitioned with different solvents in a 1:1 (v/v) using water:dichloromethane. The remaining aqueous layer was collected and evaporated by using rotary evaporator at $50-60^{\circ} \mathrm{C}[16]$.

Formulation of syrup from coffee arabica (C. arabica L.) extract The formula design of syrup from coffee arabica (C. arabica L.) extract can be seen in Table 1.

Physical stability of syrup from coffee arabica (C. arabica L.) extract was evaluated through organoleptic, $\mathrm{pH}$ and viscosity until 28 days.

\section{Bacterial contaminant test}

About $1 \mathrm{ml}$ sample was poured into $15-20 \mathrm{ml}$ of medium plate count agar. Petri dishes were incubated at $37^{\circ} \mathrm{C}$ for $24-48 \mathrm{hrs}$. Calculated colonies were grown on each Petri dish [17].

\section{Fungal contaminant test}

Sample of $0.5 \mathrm{ml}$ pipette was poured on the surface of the potatoes dextrose agar that has been added chloramphenicol. Petri dishes were incubated at a temperature of $20-25^{\circ} \mathrm{C}$ and observed until 3-5 days. Calculated colonies were grown on each Petri dish [17].

\section{Determination of CGAs in coffee}

Concentration of CGAs was detected by high performance liquid chromatography (HPLC). The mobile phase was $40 \%$ methanol:60\% water containing acetic acid $1 \%$. Mobile phase was filtered under vacuum and degassed before it would be used. The HPLC column was Enduro C-18 (4.6 × $250 \mathrm{~mm})$. The flow rate was $1 \mathrm{ml} / \mathrm{min}$. The ultraviolet (UV) absorbance was detected at $234 \mathrm{~nm}[18,19]$.

\section{Determination of caffeine in coffee}

Concentration of caffeine was detected by using HPLC. The mobile phase was methanol 37\%:water 63\%. Mobile phase was filtered under vacuum and degassed before it would be used. The HPLC column was Dionex C-18 (4.6 $\mathrm{mm} \times 250 \mathrm{~mm})$. The flow rate was $1 \mathrm{ml} / \mathrm{min}$. The UV absorbance was detected at $274 \mathrm{~nm}[20,21]$.

\section{Statistical analysis}

The data were analyzed by one-way analysis variance (ANOVA) and significant differences between the mean of the samples were determined by Newman-Keuls test. The confidence limit was set at $\mathrm{p}<0.05$.

\section{RESULTS}

The result from phytochemical screening results can be seen in Table 2 .

The result from non-specific parameters non-specific between extract and standard can be seen in Table 3.

The result from organoleptic test and specific parameters extract can be seen in Tables 4 and 5.

The result from decaffeination process can be seen in Table 6 .

Physical evaluation of syrup from coffee arabica (C. arabica L.) extract can be seen in Table 7, Figs. 1 and 2.

Bacterial and fungi count of the solution (Table 8)

Bacterial and fungi count of the solution can be seen in Table 8 .

Concentration of CGA and caffeine (Table 9)

Concentration of CGA and caffeine can be seen in Table 9

\section{DISCUSSION}

The parameters of extract including specific and non-specific parameters were approached with the reference value of seed extract arabica coffee
(C. arabica L.) that has been established by Rubiyanti et al. [22]. Water was used to keep the quality of extracts by considering the less water on simplicia and extract can avoid contaminants. However, water content in the extract and simplicia can determine acceptability, uniformity, and durability [23]. In particular, loss on drying aims to find out the amount of lost compound during the drying process that can affect the compound number of extract and simplicial [24]. Total ash levels examination describes the internal and external mineral content of extract from the beginning process. Content of acid-insoluble ash aims to find out the amount of internal and external mineral content in the extract and simplicia that cannot dissolve in the solvent acid [24].

Decaffeination was conducted by using an organic solvent, such as dichloromethane or ethyl acetate, associated with the use of water/vapor, before and after extraction. Water has been used to replace organic solvents in the process [4]. At the end of the process,

Table 1: Formulation of syrup from coffee arabica (C. arabica L.) extract

\begin{tabular}{llll}
\hline Component & $\mathbf{F}_{\mathbf{1}}$ & $\mathbf{F}_{\mathbf{2}}$ & $\mathbf{F}_{\mathbf{3}}$ \\
\hline Extract & $0.5 \mathrm{~g}$ & $0.5 \mathrm{~g}$ & $0.5 \mathrm{~g}$ \\
Sucralose & $0.05 \mathrm{~g}$ & $0.05 \mathrm{~g}$ & $0.05 \mathrm{~g}$ \\
Sodium-CMC & $0.15 \mathrm{~g}$ & $0.45 \mathrm{~g}$ & $0.75 \mathrm{~g}$ \\
Citric acid & $0.2 \mathrm{~g}$ & $0.2 \mathrm{~g}$ & $0.2 \mathrm{~g}$ \\
Sodium benzoate & $0.1 \mathrm{~g}$ & $0.1 \mathrm{~g}$ & $0.1 \mathrm{~g}$ \\
Orange essence & $1 \mathrm{ml}$ & $1 \mathrm{ml}$ & $1 \mathrm{ml}$ \\
Aquadest & Add $100 \mathrm{ml}$ & Add $100 \mathrm{ml}$ & Add $100 \mathrm{ml}$ \\
\hline
\end{tabular}

CMC: Carboxymethylcellulose

Table 2: Result of phytochemical screening

\begin{tabular}{lll}
\hline Secunder metabolic & \multicolumn{2}{l}{ Result } \\
\cline { 2 - 3 } & Dried plant material & Extract \\
\hline Alkaloids & + & + \\
Flavonoids & + & + \\
Tannins & - & - \\
Polyphenol & + & + \\
Saponin & + & + \\
Monoterpen seskuiterpen & + & + \\
Triterpenoid & + & + \\
Steroid & + & + \\
Quinons & + & + \\
\hline
\end{tabular}

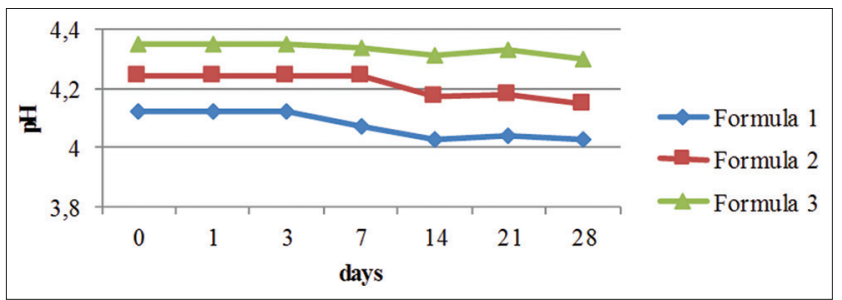

Fig. 1: $\mathrm{pH}$ measurements of the solution for $\mathbf{2 8}$ days



Fig. 2: Viscosity measurements of the solution for $\mathbf{2 8}$ days 
Table 3: Result of non-specific parameters

\begin{tabular}{lll}
\hline Parameters & Extract & Standard \\
\hline Water content $(\% \mathrm{v} / \mathrm{b})$ & $5.83 \pm 1.44$ & $5.83-6.66$ \\
Content of ash total $(\% \mathrm{~b} / \mathrm{b})$ & $1.75 \pm 0.18$ & $1.77-3.28$ \\
Content of acid insoluble ash $(\% \mathrm{~b} / \mathrm{b})$ & $0.010 \pm 0.00$ & $0.01-0.02$ \\
Loss on drying (\% b/b) & $21.83 \pm 0.76$ & $18.16-21.83$ \\
Density $(\mathrm{m} / \mathrm{v})$ & $0.91 \pm 0.00$ & $0.89-0.92$ \\
\hline
\end{tabular}

Table 4: Result of organoleptic

\begin{tabular}{lll}
\hline Parameters & Result & \\
\cline { 2 - 3 } & Dried plant material & Extract \\
\hline Shape & Oval & Viscous extract \\
Color & Green & Brown \\
Odor & Coffee & Coffee \\
\hline
\end{tabular}

Table 5: Result of specific parameters extract

\begin{tabular}{lll}
\hline Parameters & Extract & Standard \\
\hline $\begin{array}{l}\text { Content of water soluble } \\
\text { extract }(\% \mathrm{~b} / \mathrm{b})\end{array}$ & $2.50 \pm 1.32$ & $29.50-32.50$ \\
$\begin{array}{l}\text { Content of ethanol soluble } \\
\text { extract }(\% \mathrm{~b} / \mathrm{b})\end{array}$ & $35.33 \pm 1.44$ & $32.00-38.16$ \\
\hline
\end{tabular}

Table 6: Caffeine and chorogenic acid after decaffeination process

\begin{tabular}{lll}
\hline \multirow{2}{*}{ Extract } & \multicolumn{2}{l}{ Concentration (\%) } \\
\cline { 2 - 3 } & Caffeine & CGA \\
\hline Before decaffeination process & $3.377 \pm 0.091$ & $4.159 \pm 0.163$ \\
After decaffeination process & $1.028 \pm 0.079$ & $3.019 \pm 0.138$ \\
\hline CGA: Chlorogenic acid & &
\end{tabular}

Table 7: Organoleptic evaluation from extract coffee arabica syrup

\begin{tabular}{llll}
\hline Parameter & Formula $\mathbf{1}$ & Formula 2 & Formula 3 \\
\hline Flavor & ++ & ++ & ++++ \\
Odor & ++++ & ++++ & ++++ \\
Color & Orange & Orange & Orange \\
\hline
\end{tabular}

Table 8: Microbial impurities test of solution

\begin{tabular}{lll}
\hline Sample & \multicolumn{2}{l}{ Result } \\
\cline { 2 - 3 } & Bacteria & Fungi \\
\hline Negative control & - & - \\
Positive control & + & + \\
Formula 1 & - & - \\
Formula 2 & - & - \\
Formula 3 & - & - \\
\hline
\end{tabular}

-: No growth of bacteria/fungi, +: There is a growth of bacteria/fungi

Table 9: Concentration of the CGA and caffeine

\begin{tabular}{lll}
\hline \multirow{2}{*}{ Formula } & Levels of (\%) & \\
\cline { 2 - 3 } & Caffeine & CGA \\
\hline 1 & $1.270 \pm 0.150$ & $4.432 \pm 1.986$ \\
2 & $0.314 \pm 0.006$ & $1.867 \pm 0.382$ \\
3 & $0.298 \pm 0.015$ & $1.373 \pm 0.0016$ \\
\hline CGA: Chlorogenic acid & &
\end{tabular}

caffeine content is usually reduced. In the decaffeination process, losses of key flavor components of coffee generally might occur, especially when solvents, such as water, are used [25]. Dichloromethane was used because it is relatively nontoxic and has better ability to dissolve caffeine (140 mg/ml compared to water [22 mg/ml]) [12].

Although differences of CGA in decaffeinated coffees may appear to be relatively small, those may be enough to affect the flavor characteristics of the final product. The biopharmacological properties of decaffeinated coffee may differ from those caffeinated coffee due to the pharmacological actions of CGA which were "unmasked" by the absence of caffeine. However, it required further investigations [4].

Sucralose as agent was used in the formulation of syrup. As the sweetening agent, it has 300-1000 times greater of sweetness level compared to sucrose. Next to flavoring agent, citric acid was used as a buffer to stabilize $\mathrm{pH}$ of solution. In this formulation, syrup did not use sucrose as sweetening agent because it was incompatible with citric acid, which can be crystallized or hydrolyzed into dextrose and fructose [26].

Carboxymethylcellulose (CMC)-Na was used as a thickening agent since it has good stability in acidic and alkaline ( $\mathrm{pH} 2-10) 2$ [6]. Sodium benzoate was used as a preservative agent because of its high water content, which can cause contamination microbes. Plant-derived materials support the growth of microorganisms as a nutrition/food for microorganisms. In addition, preservative agent can prevent from secondary contamination, such as preparation and the environment $[27,28]$.

Regarding the $\mathrm{pH}$ observations, data were statistically analyzed by using one-way ANOVA. Previously, homogeneity and normality were analyzed using the Kolmogorov-Smirnov methods test. Since the obtained data have normal and homogeneous values, one-way ANOVA analysis method would be taken into account.

The influence of $\mathrm{pH}$ against formula was tested using one-way ANOVA method. Statistic result showed that all formulas have significant differences on the influence against $\mathrm{pH}$ value $\left(\mathrm{H}_{0}\right.$ was rejected and significant $0.00<0.05$ ). Result of Newman-Keuls test showed that every formula gave different influence against $\mathrm{pH}$.

Influence of storage time against $\mathrm{pH}$ value of each formula was analyzed using one-way ANOVA. This statistic results showed that storage time did not affect significantly the $\mathrm{pH}$ of solution $\left(\mathrm{H}_{0}\right.$ is accepted and significant $0.970>0.05$ ).

Difference of Na-CMC concentration caused different viscosities of each formula since Na-CMC has a role in viscosity value of solution [26].

The influence of formula against viscosity value was tested by using one-way ANOVA method. Statistic result showed that all formula have significant differences on the influence against viscosity value $\left(\mathrm{H}_{0}\right.$ was rejected and significant $0.00<0.05$ ). Result of Newman-Keuls test showed that every formula gave different influence against viscosity one another.

Influence of storage time against viscosity value of each formula was analyzed by using one-way ANOVA. This statistic results showed that storage time did not affect significantly the viscosity of solution $\left(\mathrm{H}_{0}\right.$ is accepted and significant $0.976>0.05$ ).

Samples in appropriate media have no growth impurities. This might be caused by the presence of sodium benzoate as preservative in solution, which worked effectively as a preservative at $\mathrm{pH}$ 3-5 [26]. The results showed that the solutions were eligible, where the bacterial count of solutions was $\leq 104$ colonies $/ \mathrm{ml}$ and the fungi count were $\leq 103$ colonies $/ \mathrm{ml}[17]$.

\section{CONCLUSION}

The concentration of caffeine before and after formulation process were $3.019 \pm 0.138 \%$ and $4.432 \pm 1.986 \%$. Formula containing $5 \mathrm{mg} / \mathrm{ml}$ of 
coffee arabica extract, $1.5 \mathrm{mg} / \mathrm{ml}$ of $\mathrm{Na} \mathrm{CMC}$ and $0.5 \mathrm{mg} / \mathrm{ml}$ of sucralose was considered as the best formula. Microbiological test showed that no contamination in syrup of coffee arabica extract. The concentration of caffeine before and after decaffeination process were $3.377 \pm 0091 \%$ and $1.028 \pm 0.079 \%$.

\section{REFERENCES}

1. Johnston KL, Clifford MN, Morgan LM. Coffee acutely modifies gastrointestinal hormone secretion and glucose tolerance in humans: Glycemic effects of chlorogenic acid and caffeine. Am J Clin Nutr 2003;78(4):728-33.

2. Kreicbergs V, Dimins F, Mikelsone V, Cinkmanis I. Biologically active compounds in roasted coffee. In: The Proceedings $6^{\text {th }}$ Baltic Conference on Food Science and Technology on Innovations for Food Science and Production. Jelgava, Latvia: LLU; c2011. p. 5-6.

3. Toci AT, Farah A. Volatile compounds as potential defective coffee beans' markers. Food Chem 2008;108(3):1133-41.

4. Farah A, de Paulis T, Moreira DP, Trugo LC, Martin PR. Chlorogenic acids and lactones in regular and water-decaffeinated arabica coffees. J Agric Food Chem 2006;54(2):374-81.

5. Trugo LC. Coffee analysis. In: Caballer B, Trugo LC, Finglas PM, editors. Encyclopedia of Food Science and Nutrition. $2^{\text {nd }}$ ed., Vol. 2. Oxford, UK: Oxford Academic Press; 2003. p. 498.

6. Farah A, de Paulis T, Trugo LC, Martin PR. Effect of roasting on the formation of chlorogenic acid lactones in coffee. J Agric Food Chem 2005;53(5):1505-13.

7. Kim SS, Park RY, Jeon HJ, Kwon YS, Chun W. Neuroprotective effects of 3,5-dicaffeoylquinic acid on hydrogen peroxide-induced cell death in SH-SY5Y cells. Phytother Res 2005;19(3):243-5.

8. Kesia RM, Gayatri C, Frenly W. Analysis of caffeine in coffee powder In Manado city using UV-VIS spectrophotometry. Pharmacon 2013;2:123.

9. Batta A, Kaur H. Coffee is a medical advice. Int J Health Sci Res 2016;6(3):286-92

10. Bawazeer NA, Alsobahi NA. Prevalence and side effects of energy drink consumption among medical students at umm Al-Qura University, Saudi Arabia. Int J Med Stud 2013;1 Suppl 3:104-8

11. Ogita S, Uefuji H, Yamaguchi Y, Koizumi N, Sano H. Producing decaffeinated coffee plants. Nature 2003;423(6942):823.

12. Atomssa T, Gholap AV. Characterization of caffeine and determination of caffeine in tea leaves using UV-visible spectrometer. Afr J Pure Appl Chem 2011;5 Suppl 1:1-8
13. Acevedo F, Rubilar M, Scheuermann E, Cancino B, Uquiche E, Garcés M, et al. Spent coffee grounds as a renewable source of bioactive compounds. J Biobased Mater Bioenerg 2013;7 Suppl 3:420-8.

14. Bpom RI. Peraturan Badan Pengawasan Obat dan Makanan Republik Indonesia Nomor 12 Tahun 2014 Tentang Persyaratan Mutu Obat Tradisional. Jakarta: 2014.

15. Luis GD, Balangcod TD, Abucay JB Jr, Wong FM, Balangcod KD, Afifi NI, et al. Phytochemical and antimicrobial screening of indigenous species that have potential for revegetation of landslides in Atok, Benguet, Philippines. Indian J Tradit Knowl 2014;13 Suppl 1:56-62.

16. Massih RA, Elias A, Elias B, Ziad D. Antibacterial activity of the extracts obtained from Rosmarinus officinalis, Origanum majorana, and Trigonella foenum-graecum on highly drug-resistant gram negative bacilli. J Bot 2010;2010:1-8.

17. Bpom RI. Metode Analisis Mikrobiologi Suplemen. Pusat Pengujian Obat dan Makanan Badan Pengawasan Obat dan Makanan Republik Indonesia. Jakarta: 2006

18. Belay A, Gholap AV. Characterization and determination of chlorogenic acids (CGA) in coffee beans by UV-vis spectroscopy. Afr J Pure Appl Chem 2009;3Suppl 11:234-40.

19. Abebe A, Kebba S. Determination of Chlorogenic Acids (CGA) in coffee beans using HPLC. Am J Res Commun 2013;1 Suppl 2:78-91.

20. Pandurang NP. Caffeine in various samples and their analysis with HPLC - A review. Int J Pharm Sci Rev Res 2012;16(2):76-83.

21. Ahmed AA. Determination of caffeine in roasted and irradiated coffee beans with gamma rays by high performance liquid chromatography. Food Sci Qual Manage 2013;22:28-34.

22. Rubiyanti R. Penetapan Parameter Standar Simplisia dan Ekstrak Biji Kopi Arabika (Coffea arabica L.) [Final Project]. Jatinangor: Fakultas Farmasi Universitas Padjadjaran; 2015. p. 68-9.

23. Saifudin A, Rahayu V, Teruna HY. Standarisasi Bahan Obat Alam. Yogyakarta: Graha Ilmu; 2011.

24. Departemen Kesehatan Republik Indonesia. Farmakope Herbal. $1^{\text {st }}$ ed. Jakarta: Departemen Kesehatan Republik Indonesia; 2008.

25. Silvarola MB, Mazzafera P, Fazioli LC. A Naturally decaffeinated arabica coffee. Nature 2004;249:826.

26. Rowe RC, Sheskey PJ, Quinn ME. Handbook of Pharmaceutical Excipients. $6^{\text {th }}$ ed. London: Pharmaceutical Press; 2009. p. 118-21, 181-3, 627-9, 701-7.

27. Budiman A, Wulandari RS, Darma GC. Anti-acne activity of papaya leaf extract in cream dossage form (Carica Papaya Linn) and honey against propionibacterium acne. Farmaka 2013;11 Suppl 2;76-87.

28. Alfauziah TQ, Budiman A. Antifungi Activity Of Essential Oil From Clove Flower In Emulsion Dossage Form. Farmaka, 2016;14(1):1-10. 